\title{
EFEKTIVITAS KONSELING KELOMPOK SFBC DENGAN TEKNIK EXCEPTION DAN MIRACLE QUESTION UNTUK MENINGKATKAN SELF CONTROL PADA SISWA PELAKU TAWURAN DI SMK NASIONAL CIREBON
}

\author{
Widayanti $^{1}$, Sugiyo ${ }^{2}$, Ali Murtadho ${ }^{3}$ \\ SMK Nasional Cirebon ${ }^{1}$ \\ Program Pascasarjana Bimbingan Konseling, Universitas Negeri Semarang ${ }^{2}$ \\ 3Fakultas Dakwah dan Komunikasi UIN Walisongo Semarang ${ }^{3}$ \\ E-mail: widayanti0520@gmail.com
}

\begin{abstract}
Abstrak
Tujuan penelitian ini (1) Untuk menganalisis tingkat keefektifan konseling kelompok SFBC dengan teknik exception dalam meningkatkan self control pada siswa pelaku tawuran di SMK Nasional Cirebon. (2) Untuk menganalisis tingkat keefektifan konseling kelompok SFBC dengan teknik miracle question dalam meningkatkan self control pada siswa pelaku tawuran di SMK Nasional Cirebon. (3) Untuk menganalisis tingkat keefektifan konseling kelompok SFBC dengan menggabungkan teknik exception dan teknik miracle question dalam meningkatkan self control pada siswa pelaku tawuran di SMK Nasional Cirebon. Metode penelitian menggunakan metode true eksperimental dengan desain pretes-post control group. Teknik analisis data menggunakan statistik deskriptif, dan statistik inferensial dengan uji beda rata-rata. Hasil penelitian ini (1) Terdapat keefektifan konseling kelompok SFBC dengan teknik exception terhadap peningkatkan self-control pada kelompok A pada hasil uji hipotesis dengan analisis paired sample test. (2) Terdapat keefektifan konseling kelompok SFBC dengan teknik miracle question terhadap peningkatan self-control pada kelompok B, pada hasil uji hipotesis dengan analisis uji Wilcoxon. (3) Terdapat keefektifan konseling kelompok SFBC dengan gabungan teknik exception dan teknik miracle question terhadap peningkatan self-control pada kelompok $\mathrm{C}$ pada hasil uji hipotesis dengan analisis paired sample test.

Kata kunci: konseling kelompok, sfbc, exception, miracle question, self control
\end{abstract}

\begin{abstract}
The purpose of this study (1) To analyze the effectiveness of SFBC group counseling with exception techniques in increasing self control of students who fight in the National Vocational School of Cirebon. (2) To analyze the effectiveness of SFBC group counseling with miracle question techniques in improving self control of brawler students in Cirebon National Vocational School. (3) To analyze the effectiveness of SFBC group counseling by combining exception techniques and miracle question techniques in improving self control of students who fight in the National SMK Cirebon. The research method uses true experimental method with pretest-post control group design. Data analysis techniques using descriptive statistics, and inferential statistics with the average difference test. The results of this study (1) There is the effectiveness of SFBC group counseling with exception techniques to improve self-control in group $A$ on the results of hypothesis testing with paired sample test analysis. (2) There is an effectiveness of SFBC group counseling with miracle question technique to increase self-control in group $B$, on the results of hypothesis testing with Wilcoxon test analysis. (3) There is effectiveness of SFBC group counseling with a combination of exception techniques and miracle question techniques to increase self-control in group $C$ on the results of hypothesis testing with paired sample test analysis.
\end{abstract}

Keywords: group counseling, $s f b c$, exception, miracle question, self control

\section{Info Artikel}

Diterima Februari 2020, disetujui Maret 2020, diterbitkan Juni 2020 


\section{PENDAHULUAN}

Dalam konseling ada banyak alternatif pendekatan dan teknik yang telah terbukti efektif untuk digunakan sebagai therapy bagi siswa yang memiliki self control yang rendah diantaranya yaitu penelitian yang dilakukan oleh Arumsari (2016) membuktikan bahwa konseling individu dengan teknik modeling simbolis efektif mengembangkan kontrol diri tiga siswa subjek penelitian pada semua sapek self control yaitu perasaan dan tingkah laku, disiplin, emosi dan nafsu. Penelitian oleh Ariningsun \& Pratiwi (2014) membuktikan bahwa pemberian konseling kelompok rasional emotif perilaku dapat meningkatkan self control siswa kelas VIII SMP Negeri 4 Panggul Trenggalek. Sehingga asusmsi peneliti bahwa konseling dengan pendekatan SFBC juga efektif untuk meningkatkan self control siswa.

Teknik terapi Solution-Focused Brief Counseling, antara lain: Fokus pada perubahan (focusing of change), percakapan bebas masalah (problem free talk), menemukan pengecualian (exception), pertanyaan ajaib (miracle question), pertanyaan berskala (scalling question), tugas rumah (mengeksplorasi sumber daya), Memberikan pujian (Compliments counts), mengatasi pertanyaan (coping questions), membentuk hubungan kolaboratif (forming a collaborative relationship). Dan dalam penelitian ini, konselor menggunakan dua teknik dari sepuluh teknik yang ada pada terapi SFBC, yaitupengecualian (exception) dan pertanyaan ajaib (miracle question).

Teknik exception (pengecualian) dianggap esensial bagi pendekatan SFBC karena teknik ini memberikan solusi pada "masalah". exception berasumsi bahwa semua masalah memiliki pengecualian yang dapat digunakan untuk memfasilitasi solusi. Dengan cara ini, konseli mempunyai harapan dan diberdayakan oleh kemampuannya untuk mempengaruhi lingkungannya (Erford, 2016).

Terapi SFBC menanyakan pertanyaan-pertanyaan exception untuk mengarahkan konseli pada waktu ketika masalah tersebut tidak ada atau ketika masalah tidak begitu intens. Exception merupakan pengalaman - pengalaman masa lalu dalam kehidupan konseli ketika pantas mempunyai beberapa harapan masalah tersebut terjadi, tetapi bagaimanapun juga tetap tidak terjadi (de Shazer dalam Corey 2009). Eksplorasi ini mengingatkan konseli bahwa masalah-masalah tidak semua kuat dan tidak selamanya ada, tetapi jugamemberikan kesempatan untuk membangkitkan sumber daya, 
menggunakan kekuatan kekuatan danmenempatkan solusi-solusi yang mungkin. Dalam kosa kata fokus solusi, ini disebut change-talk (Corey, 2009).

Teknik miracle question (pertanyaan ajaib) memaksa konseli untuk mempertimbangkan apa yang betul-betul mereka inginkan, bukan sekedar apa yang tidak mereka inginkan sehingga konseli menemukan kemungkinan-kemungkinan yang sebelumnya tidak disadari. Dengan kata lain, jika konseli tidak pernah mempertimbangkan yang "labih baik" itu seperti apa, bagaimana konseli akan mengenalinya begitu hal itu tercapai?, dan dalam prosesnya mencapai jalur fokus solusi, menekankan harapan akan masa depan yang lebih baik sebagai upaya untuk menetapkan apa yang diinginkannya (Erford, 2016).

Adapun perbedaan dengan penelitian yang ingin peneliti lakukan yaitu ada pada pendekatan dan teknik yang digunakan, penelitian ini menggunakan konseling kelompok solution focused brief counseling (SFBC) dimana pendekatan ini menekankan pada asumsi bahwa individu memiliki kekuatan diri, asumsi dasar ini sejalan dan sesuai untuk meningkatkan self control.

Penelitian ini berfokus pada siswa kelas X SMK Nasional Cirebon dengan perilaku tawuran kategori sedang dan tinggi serta kemampuan self control yang rendah. Penelitian ini menggunakan kerangka teori konseling kelompok SFBC dengan teknik exception dan miracle question sebagai intervensi untuk membantu siswa dengan perilaku tawuran dalam meningkatkan self control.

Berdasarkan fenomena yang telah dipaparkan sebelumnya, dan pentingnya meningkatkan self control serta kelebihan dari pendekatan konseling berfokus solusi oleh karena itu, peneliti tertarik untuk menguji cobakan tentang efektivitas konseling kelompok SFBC dengan teknik exception dan teknik miracle question untuk meningkatkan self control pada siswa pelaku tawuran di SMK Nasional Cirebon.

Tujuan penelitian ini adalah (1) Untuk menganalisis tingkat keefektifan konseling kelompok SFBC dengan teknik exception dalam meningkatkan self control pada siswa pelaku tawuran di SMK Nasional Cirebon. (2) Untuk menganalisis tingkat keefektifan konseling kelompok SFBC dengan teknik miracle questiondalam meningkatkan self control pada siswa pelaku tawuran di SMK Nasional Cirebon. (3) Untuk menganalisis tingkat keefektifan konseling kelompok SFBC dengan 
menggabungkan teknik exception dan teknik miracle question dalam meningkatkan self control pada siswa pelaku tawuran di SMK Nasional Cirebon.

\section{METODE PENELITIAN}

Penelitian ini dilakukan dengan menggunakan desain Randomized pretestposttest Comparasion Group Design. Purwanto (2016:131) menyebutkan bahwa desain Randomized pretest-posttest Comparasion Group Design merupakan desain yang paling baik dalam mengontrol ancaman validitas internal. Langkahnya yaitu melakukanpretest mengenai self control siswa yang merupakan pelaku tawuran sehingga diketahui tingkat self control tinggi, sedang dan rendah. Kemudian dilakukan random assignment terhadap subyek untuk dibentuk dalam kelompok eksprimen lalu diberikan intervensi dan terakhir posttest.

Subyek dalam penelitian ini adalah siswa SMK Nasional Cirebon yang berjumlah 21 anak, kriteria pemilihan subyek dalam penelitian ini adalah siswa kelas $\mathrm{X}$ yang menjadi pelaku tawuran dengan tingkat self control sedang dan rendah.

Instrumen penelitian ini dikembangkan dari karakteristik self controlyang terdiri dari 5 aspek yaitu : (1) Self-Discipline (kedisiplinan diri), (2) Deliberate/Non Impulsive(Pengendalian tindakan impulsif), (3) Healthy Habits(Kebiasaan hidup sehat) (4) Work Ethic(etos kerja), (5) Reliability (keandalan diri). Masing-masing aspek dibagi lagi ke dalam beberapa indikator dan selanjutnya dijabarkan dalam bentuk pernyataan Aitem instrumen. Teknik analisis data menggunakan statistic deskriptif dan inferensial dengan uji beda rerata secara parametric atau non parametric.

\section{HASIL DAN PEMBAHASAN}

Bab ini akan menguraikan hasil penelitian yang telah dilaksanakan disertai dengan analisis data dan pembahasan mengenai efektivitas konseling kelompok solution focused brief counseling (SFBC) dengan teknik exception dan miracle question untuk meningkatkan self control pada siswa pelaku tawuran di SMK Nasional Cirebon.

Dalam penelitian ini analisis deskriptif kuantitatif yang digunakan melalui perhitungan rata-rata (mean) dan standar deviasi (SD). Analisis ini digunakan untuk melihat tingkat self control siswa sebelum (pre-test) di berikan intervensi. Untuk melihat tingkat self control siswa di SMK Nasional sebelum (pre-test) padakelompok 
SFBC dengan teknik exception, teknik miracle question maupun pada kelompok gabungan teknik exception dan teknik miracle question, di sajikan pada tabel 3.1 berikut:

\section{Tabel 1. Kategori Self Control Siswa pada Pre-Test}

\begin{tabular}{lllll} 
& & \multicolumn{2}{c}{$\mathbf{O}_{\mathbf{1}}$} & \multirow{2}{*}{ Kategori } \\
\cline { 3 - 4 } & $\mathbf{N}$ & $\mathrm{M}$ & $\mathrm{SD}$ & \\
\hline KA & 7 & 59,4 & 1,9 & Rendah \\
KB & 7 & 67,7 & 1,7 & Sedang \\
KC & 7 & 68,6 & 1,6 & Sedang \\
\hline Total & 21 & 196 & 5,2 & Sedang \\
\hline
\end{tabular}

Ket: $\quad \mathrm{O}_{1}: \quad$ KA: Kelompok exception
Pre-test
M: Rata-rata

Pola tingkat self control siswa pelaku tawuran berdasarkan setiap kelompok penelitian berdasarkan hasil penelitian dari data awal sebelum di berikan intervensi konseling kelompok SFBC menunjukkan tingkat self control pada masing-masing kelompok dengan perlakuan yang berbeda yaitu pada kelompok A sebelum diberikan intervensi konseling kelompok SFBC dengan teknik exception, dari hasil pre-test menjelaskan tingkat self control kategori rendah dengan $\mathrm{M}=59,4$ dan $\mathrm{SD}=1,9$ dan pada kelompok B sebelum diberikan intervensi konseling kelompok SFBC dengan teknik miracle question dari hasi pre-test menjelaskan tingkat self control kategori sedang dengan $\mathrm{M}=67,7$ dan $\mathrm{SD}=1,7$. Sedangkan pada kelompok $\mathrm{C}$ sebelum di berikan intervensi konseling kelompok SFBC dengan gabungan teknik exception dan miracle question hasil pre-test menunjukkan tingkat self control sedang dengan $M=68,6$ dan $\mathrm{SD}=1,6$. Berdasarkan hasil observasi sebelum diberikan intervensi konseling kelompok SFBCpada dasarnya mereka memiliki masalah yang serupa yaitu pola sikap konseli cenderung mengalami gangguan suasana hati, mereka cepat mengalami emosi marah, dan kurang dapat mengendalikan luapan emosinya itu. 
Tabel 2. Kategori Self Control Siswa pada Post-Test

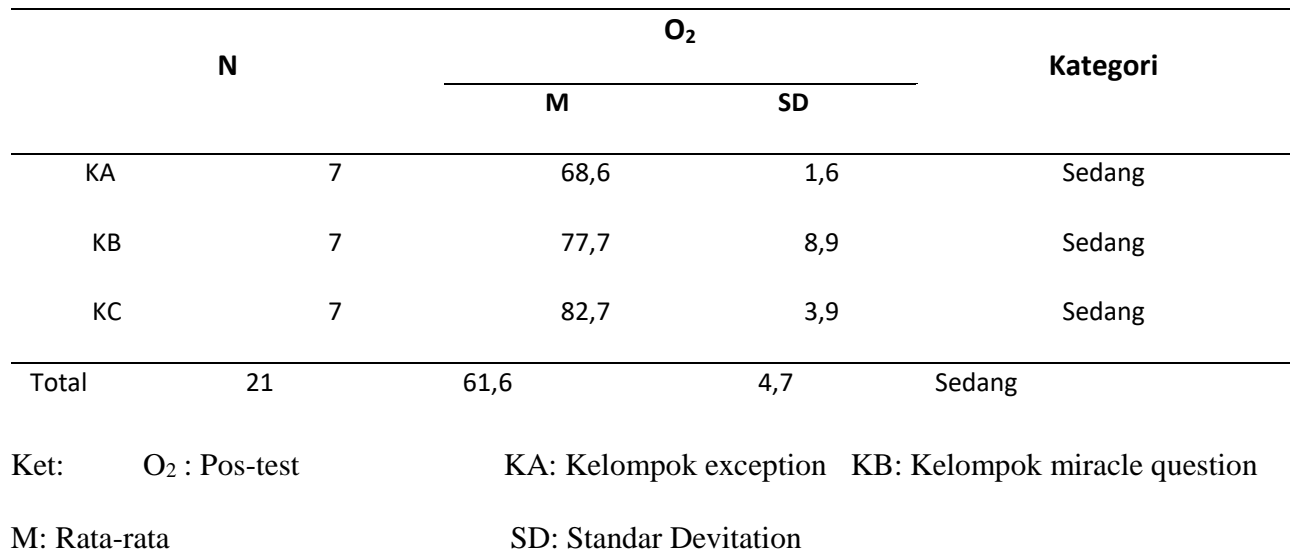

Berdasarkan uji statistik terlihat perubahan yang signifikan pada konseli dengan intervensi konseling kelompok SFBC. Peningkatan self control terjadi pada masingmasing kelompok A,kelompok B dan kelompok C. Hasil poss-test ketiga kelompok setelah di berikan intervensi konseling kelompok SFBC memang tidak mengalami perubahan pada kategori tingkat self control, namun masing-masing terdapat peningkatan jika dilihat dari nilai rata-rata yang ditunjukkan dari pre-test ke post-test. Dan kelompok B meskipun mengalami peningkatan tetapi tidak sebanyak peningkatan pada kelompok Adan kelompok C. Pada kelompok A hasil pre-test $\mathrm{M}=68,6$ dan $\mathrm{SD}=$ 1,6. Pada kelompok B hasil post-test $\mathrm{M}=77,7$ dan $\mathrm{SD}=8,9$. Selain itu, pada kelompok C mengalami peningkatan self control paling tinggi, yaitu $\mathrm{M}=82,7$ dan $\mathrm{SD}=3,9$.

Pola setelah post-test di atas menggambarkan bahwa individu dengan memiliki kesadaran dan ketenangan yang di dapat dari kelebihan konseling kelompok SFBCdapat membantu individu membentuk self control. Dari hasil pengamatan, terlihat adanya perubahan terapeutik pada diri konseli, yaitu ditandai dengan perubahan pola bersikap yang lebih dapat mengendalikan diri. Perubahan sikap tersebut mengarah pada pemaknaan self control yang tinggi. Konseli menjadi pribadi yang memiliki kedisiplinan diri, pengendalian tindakan Impulsif, kebiasaan baik, etos kerja, pengeandalan diri. Karakteristik yang ditunjukkan konseli sesuai dengan karakteristik self control yang tinggi menurut Tangney (2004), 
Kelompok pertama merupakan kelompok yang mendapatkan perlakuan berupa konseling kelompok SFBC dengan teknik exception. Sebelum diberikannya layanan konseling kelompok SFBC dengan teknik exception untuk meningkatkan self control siswa di SMK Nasional terlebih dahulu dilakukan pemilihan subjek penelitian. Pemilihan subjek penelitian dalam penelitian ini dilakukan secara purposive sampling pada kelas $\mathrm{X}$ dengan mengambil 7 orang siswa. Kemudian subjek penelitian tersebut diarahkan untuk mengisi skala self control sebelum (pre-test) dan setelah (post-test) dalam pemberian layanan konseling kelompok SFBC dengan teknik exception untuk melihat pengaruh layanan yang diberikan terhadap perubahan self control subjek penelitian. Hasil pengukuran tersebut dapat di lihat pada tabel di bawah ini:

Tabel 3. Tingkat Self Control Pre_Test-Post_Test pada Kelompok A, B dan C

\begin{tabular}{|c|c|c|c|c|}
\hline \multirow{2}{*}{ Kelompok } & \multicolumn{4}{|c|}{$\mathrm{O}_{1}-\mathrm{O}_{2}$} \\
\hline & $\mathbf{N}$ & $\mathbf{M}$ & SD & $\mathbf{p}$ \\
\hline \multirow[t]{2}{*}{ KA } & & 59,4 & 1,9 & \\
\hline & 7 & 68,6 & 1,6 &, 000 \\
\hline \multirow[t]{2}{*}{$\mathrm{KB}$} & & 67,7 & 1,7 & \\
\hline & 7 & 77,7 & 8,9 & ,021 \\
\hline \multirow[t]{2}{*}{$\mathrm{KC}$} & & 68,6 & 1,6 & \\
\hline & 7 & 82,7 & 3,9 & ,000 \\
\hline Total & 21 & & & \\
\hline
\end{tabular}

Ket: $\mathrm{O}_{1}$ : Pre-Test $\mathrm{O}_{2}$ : Pos-test 〈A: Kelompok exception

M: Rata-rata

p: Signifikansi iD: Standar Devitation
KB: Kelompok miracle question

KC: question 


\section{Hasil Untuk Tingkat Self Control Pada Kelompok A}

Tabel 4.4 menunjukkan hasil uji parired sampel t test untuk self-control kelompok A, uji paired sampel t test adalah metode statistik parametrik yang di gunakan untuk data berdistribusi normal (uji normalitas). Hasil uji paired sampel t test sebagai berikut:

Tabel 4. Hasil Uji Paired sample t-test Kelompok A

\section{Paired Samples Test}

\begin{tabular}{|c|c|c|c|c|c|c|c|c|}
\hline & \multicolumn{5}{|c|}{ Paired Differences } & \multirow[b]{3}{*}{$\mathrm{t}$} & \multirow[b]{3}{*}{ df } & \multirow{3}{*}{$\begin{array}{l}\text { Sig. (2- } \\
\text { tailed) }\end{array}$} \\
\hline & \multirow[b]{2}{*}{ Mean } & \multirow{2}{*}{$\begin{array}{l}\text { Std. } \\
\text { Deviation }\end{array}$} & \multirow{2}{*}{$\begin{array}{l}\text { Std. } \\
\text { Error } \\
\text { Mean }\end{array}$} & \multicolumn{2}{|c|}{$\begin{array}{l}95 \% \text { Confidence Interval of } \\
\text { the Difference }\end{array}$} & & & \\
\hline & & & & Lower & Upper & & & \\
\hline $\begin{aligned} \text { Pair } 1 & \text { Pre_test - } \\
& \text { Post_test }\end{aligned}$ & -9.143 & 1.464 & .553 & -10.497 & -7.789 & -16.525 & 6 & .000 \\
\hline
\end{tabular}

1. Berdasarkan tabel 3.4 untuk kelompok A, dapat di interpretasikan bahwa dari total data sebanyak 7 subjek penelitian, pada pre-test $\mathrm{M}=59,4$ dan $\mathrm{SD}=1,9$. Pada posttest $\mathrm{M}=68,6$ dan $\mathrm{SD}=1,6$

2. Dari interpretasi diatas dapat dipahami bahwa tingkat Self Control pada kelompok A sesudah diberikan konseling kelompok SFBC dengan teknik exception lebih tinggi dari pada sebelum diberikan konseling kelompok SFBC dengan teknik exception. Hal ini menunjukkan terjadi peningkatan tingkat self-control setelah diberikan perlakuan.

3. Adapun pengambilan keputusan terhadap hasil uji hipotesis untuk self-control kelompok A, yaitu:

4. Ho : Konseling Kelompok SFBC dengan teknik exception tidak berpengaruh terhadap meningkatkan self-control.

5. Ha : Konseling Kelompok SFBC dengan teknik exception berpengaruh terhadap meningkatkan self-control.

Pengambilan keputusan ada atau tidaknya pengaruh, hasil perhitungan menggunakan taraf signifikansi 5\% melalui ketentuan sebagai berikut:

1. Jika nilai signifikasi atau Sig ( 2 tailed) $>\mathbf{0 , 0 5}$, maka Ho diterima dan Ha ditolak.

2. Jika nilai signifikasi atau Sig ( 2 tailed) $<\mathbf{0 , 0 5}$, maka Ha diterima dan Ho ditolak. 
Berdasarkan hasil uji Paired Sample Test untuk self-control kelompok A pada tabel 4.2, dapat di lihat nilai Sig $=0,000$ lebih kecil dari pada $0,05(\mathbf{0 , 0 0 0}<\mathbf{0 , 0 5})$ maka Ha diterima dan Ho ditolak, dengan demikian dapat di simpulkan bahwa konseling kelompok SFBC dengan teknik exception terdapat perubahan yang signifikan terhadap peningkatan self-control pada siswa pelaku tawuran di SMK Nasional Cirebon.

Tabel 5, menunjukkan hasil uji wilcoxon untuk self-control kelompok $\mathrm{B}$, uji wilcoxon adalah metode statistik non parametrik yang di gunakan sebagai alternatif dari uji paired sampel t test, sebab data penelitian untuk kelompok B setelah di lakukan normalitas di dapatkan data yang tidak berdistribusi normal, sehingga data tersebut tidak memenuhi syarat dalam pengujian statistik parametrik khususnya uji paired sample t test. Hasil uji wilcoxon sebagai berikut:

Tabel 5. Hasil Uji Wilcoxon Kelompok B

Test Statistics $^{b}$

\begin{tabular}{|l|r|}
\hline & Pos_Test - Pre_Test \\
\hline$Z$ & $-2.120^{\mathrm{a}}$ \\
\hline Asymp. Sig. (2-tailed) & $\mathbf{. 0 3 4}$ \\
\hline & \\
a. Based on negative ranks. \\
b. Wilcoxon Signed Ranks Test
\end{tabular}

Berdasarkan tabel tingkat self-control untuk kelompok $\mathrm{B}$, dapat di interpretasikan bahwa dari total data sebanyak 7 data,pada nilai pre-test $M=67,7$ dan $\mathrm{SD}=1,7$. Sedangkan nilai post-test $\mathrm{M}=77,7$ dan $\mathrm{SD}=8,9$.

Dari interpretasi diatas dapat dipahami bahwa tingkat Self Control pada kelompok B sesudah diberikan konseling kelompok SFBC dengan teknik miracle question lebih tinggi dari pada sebelum diberikan konseling kelompok SFBC dengan teknik miracle question. Hal ini menunjukkan terjadi peningkatan tingkat self-control setelah diberikan perlakuan.

Pengambilan keputusan ada atau tidaknya pengaruh, hasil perhitungan menggunakan taraf signifikansi 5\% melalui ketentuan sebagai berikut:

1. Jika nilai signifikasi atau Sig ( 2 tailed) $>0,05$, maka Ho diterima dan Ha ditolak.

2. Jika nilai signifikasi atau Sig (2 tailed) $<0,05$, maka Ha diterima dan Ho ditolak

Untuk self-control kelompok B, nilai Sig sebesar 0,021 lebih kecil dari pada 0,05 $(\mathbf{0 , 0 3 4}<\mathbf{0 , 0 5})$, hal ini berarti terdapat perubahan pada kelompok B dari pre-test ke posttest, sehingga hasil hipotesis Ha di terima dan Ho di tolak. 
Tabel 6 akan menunjukkan hasil uji paired sampel t testuntuk self-control kelompok $\mathrm{C}$, uji paired sampel t test adalah metode statistik parametrik yang di gunakan untuk data berdistribusi normal (uji normalitas). Hasil uji paired sampel t test sebagai berikut:

Tabel 6. Hasil Uji Paired sample t-test Kelompok C

\begin{tabular}{|c|c|c|c|c|c|c|c|c|}
\hline & \multicolumn{5}{|c|}{ Paired Differences } & \multirow[b]{3}{*}{$\mathrm{t}$} & \multirow[b]{3}{*}{ df } & \multirow{3}{*}{$\begin{array}{l}\text { Sig. (2- } \\
\text { tailed) }\end{array}$} \\
\hline & \multirow[b]{2}{*}{ Mean } & \multirow{2}{*}{$\begin{array}{l}\text { Std. } \\
\text { Deviation }\end{array}$} & \multirow{2}{*}{$\begin{array}{l}\text { Std. Error } \\
\text { Mean }\end{array}$} & \multicolumn{2}{|c|}{$\begin{array}{l}95 \% \text { Confidence Interval of the } \\
\text { Difference }\end{array}$} & & & \\
\hline & & & & Lower & Upper & & & \\
\hline $\begin{aligned} \text { Pair } 1 & \text { Pre_test - } \\
& \text { Post_test }\end{aligned}$ & -14.143 & 3.848 & 1.455 & -17.702 & -10.584 & -9.723 & 6 & .000 \\
\hline
\end{tabular}

Berdasarkan tabel 3.6 untuk kelompok C, dapat di interpretasikan bahwa dari total data sebanyak 7 subjek penelitian, pada pre-test $\mathrm{M}=68,6$ dan $\mathrm{SD}=1,6$. Sedangkan nilia pada post-test $\mathrm{M}=82,7 \mathrm{dan} \mathrm{SD}=3,9$.

Dari interpretasi diatas dapat dipahami bahwa tingkat Self Control pada kelompok $\mathrm{C}$ sesudah diberikan konseling kelompok SFBC dengan gabungan teknik exceptiondan teknik miracle question lebih tinggi dari pada sebelum diberikan konseling kelompok SFBC dengan gabungan teknik exceptiondan miracle question. Hal ini menunjukkan terjadi peningkatan tingkat self-control setelah diberikan perlakuan.

Pengambilan keputusan ada atau tidaknya pengaruh, hasil perhitungan menggunakan taraf signifikansi 5\% melalui ketentuan sebagai berikut:

1. Jika nilai signifikasi atau Sig ( 2 tailed) $>\mathbf{0 , 0 5}$, maka Ho diterima dan Ha ditolak.

2. Jika nilai signifikasi atau Sig ( 2 tailed) $<\mathbf{0 , 0 5}$, maka Ha diterima dan Ho ditolak.

Berdasarkan hasil uji Paired Sample Test untuk self-control kelompok B pada tabel 4.2, dapat di lihat nilai Sig $=0,000$ lebih kecil dari pada $0,05(\mathbf{0 , 0 0 0}<\mathbf{0 , 0 5})$ maka Ha diterima dan Ho ditolak, dengan demikian dapat di simpulkan bahwa konseling kelompok SFBC dengan gabungan teknik exception dan miracle question terdapat perubahan yang signifikan terhadap peningkatan self-control pada siswa pelaku tawuran di SMK Nasional Cirebon.

Analisis ini dilakukan dengan Uji Kruskal-Wallis dengan program SPSS for Windows versi 21 untuk mengetahui besarnya perbedaan kelompok A, B dan kelompok C pada saat pre-test maupun post-test. 
Uji Kruskal-Wallis adalah metode statisti non parametrik yang di gunakan sebagai alternatif dari uji One-Way ANOVA ketika salah satu atau seluruh sebaran data tidak berdistribusi normal, adapun data penelitian untuk kelompok A dan B berdistribusi normal sedangkan data untuk kelompok B setelah di lakukan uji normalitas di dapatkan data tidak berdistribusi normal, sehingga data tersebut tidak memenuhi syarat dalam pengujian statistik parametrik.

Ada pun pengambilan keputusan terhadap hasil uji hipotesis pada pre-test dan post-test, yaitu :

1. Ho : tidak terdapat perbedaan antara kelompok A, B dan kelompok C

2. Ha : terdapat perbedaan antara kelompok A, B dan kelompok C

Tabel 7. Perbedaan Tingkat Self-control antara Kelompok A, B dan C

\begin{tabular}{|c|c|c|c|c|}
\hline \multirow{2}{*}{ Kelompok } & \multicolumn{4}{|c|}{$\mathrm{O}_{1}-\mathrm{O}_{2}$} \\
\hline & $\mathrm{N}$ & M & df & $\mathrm{P}$ \\
\hline KA & 7 & $\begin{array}{l}4,00 \\
5,07 \\
\end{array}$ & & \\
\hline $\mathrm{KB}$ & 7 & $\begin{array}{l}13,6 \\
12,4 \\
\end{array}$ & $\begin{array}{l}2 \\
2 \\
\end{array}$ & $\begin{array}{l}, 00 \\
, 005\end{array}$ \\
\hline $\mathrm{KC}$ & 7 & $\begin{array}{l}15,4 \\
15,5\end{array}$ & & \\
\hline Total & 21 & & & \\
\hline \multicolumn{5}{|l|}{ Ket : } \\
\hline $\mathrm{O}_{1}$ : Pre-test & $\mathrm{O}_{2}$ : Post-test & N: Subjek Penelitian & KA: & eption \\
\hline P : Signifikansi & $\begin{array}{l}\text { M: Mean } \\
\text { Rank }\end{array}$ & $\begin{array}{l}\text { KB: Kelompok miracle } \\
\text { question }\end{array}$ & $\begin{array}{l}\mathrm{KC}: \\
\text { exc }\end{array}$ & $\begin{array}{l}\text { le question } \\
\text { le }\end{array}$ \\
\hline
\end{tabular}

Berdasarkan pada tabel di atas untuk data pre-test, menunjukkan terdapat 7 data pre-testdari masing-masing kelompok A, B dan kelompok C.Mean ranktingkat selfcontrol pada saat pre-test untuk kelompok $\mathrm{A}=4,00$ sedangkan mean rank untuk tingkat self-control pada saat pretest untuk kelompok $\mathrm{B}=5,07$ dan mean rankuntuk kelompok $\mathrm{C}$ $=15,4$. Dengan sig $=, 001$.Berdasarkan data untuk mean ranks pada kelompok A, B dan C menunjukkan bahwa tingkat self-control antara kelompok A, B dan kelompok C sebelum diberikan konseling kelompok SFBC menunjukkan paling tinggi ada pada kelompok $\mathrm{C}$ dan paling rendah pada kelompok $\mathrm{A}$. 
Pengambilan keputusan ada atau tidaknya pengaruh, hasil perhitungan menggunakan taraf signifikansi 5\% melalui ketentuan sebagai berikut:

1. Jika sign. (p) >0,05, maka Ho diterima.

2. Jika sign. (p) $<0.05$, maka Ho ditolak.

Pada kasus ini terlihat bahwa pada pre-test, signifikansi $=0,001<0,05$, maka Ho ditolak dan Ha diterima, artinya hipotesis menyatakan bahwa tidak terdapat perbedaan antara hasil pre-test kelompok A, B dan kelompok C ditolak. Berarti terdapat perbedaan pada saat pre-test antara kelompok A, B dan kelompok C.

Sedangkan untuk data post-test pada tabel 3, menunjukkan terdapat masingmasing 7 data post-testdari kelompok A, B dan 7 data post-test kelompok C.Mean rank untuk data tingkat self-control pada saat post-test untuk kelompok $\mathrm{A}=5,07$, sedangkan mean rank untuk tingkat self-controlpada saat post-test untuk kelompok $B=12,4$ dan mean rank untuk tingkat self-control pada saat post-test untuk kelompok $C=15,5$. Dengan sig $=\mathbf{0 , 0 0 5}$.

Berdasarkan data untuk mean ranks diketahui bahwa tingkat mean rank untuk tingkat self-control pada saat post-test untuk kelompok A, B dan kelompok C, setelah diberikan konseling kelompok SFBC menunjukkan paling tinggi ada pada kelompok $\mathrm{C}$ dan paling rendah pada kelompok A.

Pengambilan keputusan ada atau tidaknya pengaruh, hasil perhitungan menggunakan taraf signifikansi 5\% melalui ketentuan sebagai berikut:

1. Jika sign. (p) $>0,05$, maka Ho diterima.

2. Jika sign. (p) < 0.05, maka Ho ditolak.

Pada kasus post-tesini terlihat bahwa signifikansi $(\mathrm{p})=\mathbf{0 , 0 0 5}<\mathbf{0 , 0 5}$, maka Ho ditolak dan Ha diterima, artinya hipotesis yang menyatakan bahwa tidak terdapat perbedaan antara kelompok A, B dan kelompok C saat post-test ditolak, berarti terdapat perbedaan pada saat post-test antara kelompok A, B dan kelompok C.

Sehingga kesimpulan akhir dari analisis yang dilakukan dengan Uji paired sampel test, Uji Wilcoxon Signed Ranks Test dan Uji Kruskal-Wallis didapatkan bahwa konseling kelompok SFBC dengan teknik exception pada kelompok A, teknik miracle question pada kelompok B dan gabungan teknik exception dan teknik miracle question pada kelompok $\mathrm{C}$ efektif terhadap peningkatan self-control pada siswa pelaku tawuran di SMK Nasional. 
Pembahasan penelitian mengenai efektifitas konseling kelompok SFBC dengan teknik exception dan teknikmiracle question terhadap peningkatkan self-control pada siswa pelaku tawuran di SMK Nasional Cirebon berdasarkan hasil penelitian yang sudah dilakukan peneliti, akan dibahas lebih lanjut pada bagian ini.

Dilihat dari hasil pre-test pada tabel 1 menunjukkan siswa pelaku tawuran memiliki kategori tingkat self-control yang rendah dan sedang pada kelompok A, B dan kelompok C. Hal ini relevan dengan hasil penelitian sebelumnya bahwa adanya hubungan antara self-control dan agresi atau tawuran juga diungkapkan oleh Dewall, Finkel \& Denson (2011) yang dalam penelitiannya menyatakan bahwa kegagalan selfcontrol dapat memberikan kontribusi untuk tindakan agresif bahkan yang menyertakan kekerasan. Hal ini juga turut diungkapkan oleh Moyer \& Susetyo 1999 (dalam Zahri \& Savira, 2016) bahwa agresivitas berkaitan dengan kurangnya kontrol terhadap emosi dalam diri individu. Remaja dengan tingkat self control yang tinggi akan mampu untuk mempertimbangkan konsekuensi dari perbuatan mereka dan dapat menghindari berperilaku agresif (Sentana \& Kumala, 2017).

Penelitian serupa menyatakan bahwa individu dengan self control yang rendah memliki karakteristik untuk melakukan tindakan-tindakan pidana atau tindakan yang menyimpang lainnya dalam kehidupan bersosial Gottfredson \& Hirschi (dalam Titisari, 2018). Oleh karena itu self controlpenting untuk ditingkatkan oleh siswa agar agar jauh dari perilaku impulsif yang melanggar standar perilaku, agar membuat individu menampilkan perilaku yang sesuai dengan tuntutan lingkungannya sehingga tidak akan menimbulkan keresahan dalam berhubungan dengan dirinya sendiri dan orang lain. Individu biasanya memiliki kesulitan untuk menolak kesenangan yang menghampirinya, meskipun kesenangan akan memberikan dampak atau konsekuensi negatif di masa yang akan datang. (Tangney et al, 2004; Ghufron \& Risnawati, 2014).

Dari tabel 2 dapat dilihat pola self-controlpada kelompok B, dimana kategori tingkat self-control pada pre-tes ke post-testidak mengalami perubahan yang besar. Meskipun peningkatan self-control secara data kuantitatif tidak signifikan, namun terlihat sikap siswa setelah mengikuti konseling kelompok SFBC dengan teknik exception mengalami perubahan dari keadaan sebelumnya, sebab di dalam intervensi psikologi di yakini bahwa perubahan kecil bisa membuka jalan untuk perubahan yang 
lebih besar karena permasalahan apapun dapat diselesaikan dengan tahap demi tahap (Corey, 2013).

Selanjutnya pada tabel 2 juga terlihat kelompok $\mathrm{C}$ yang memiliki perubahan self-control yang cukup tinggi dari pre-test ke post-test. Hal ini karena setelah mengikuti konseling kelompok SFBC dengan teknik gabungan exception dan teknikmiracle question siswa pelaku tawuran merasa mempunyai harapan dan diberdayakan oleh kemampuannya untuk mempengaruhi lingkungannya dan memiliki harapan akan masa depan yang lebih baik sebagai upaya untuk menetapkan apa yang diinginkannya (Erford, 2016). Hal tersebut sesuai dengan teori (Tangney et al., 2004:271) yang menyatakan bahwa komponen utama dari self-control adalah suatu kemampuan untuk mengesampingkan atau mengubah respon di dalam diri seseorang, serta menghilangkan kecenderungan perilaku yang tidak diinginkan dan menahan diri dari suatu tindakan yang dilakukan, yang aspek-aspeknya yaitu self-discipline (kedisiplinan diri), deliberate/non-impulsive (pengendalian tindakan impulsif), healthy habits (kebiasaan baik), work ethic (etos kerja), reliability (keandalan diri).

Uji keefektifan intervensi bertujuan untuk mengetahui apakah konseling kelompok SFBC dengan teknik exception dan miracle question efektif terhadap peningkatan self-control pada siswa pelaku tawuran di SMK Nasional Cirebon. Dari hasil penelitian ini diketahui bahwa konseling kelompokdengan teknik exception dan miracle question memiliki pengaruh terhadap peningkatan self-control pada siswa pelaku tawuran di SMK Nasional Cirebon. Pelaksanaan konseling kelompok SFBC dalam penelitian ini bertujuan untuk membantu siswa berasumsi optimis bahwa setiap manusia adalah sehat dan kompeten serta memiliki kemampuan dalam membuat solusi yang dapat meningkatkan kualitas hidupnya dengan optimal walaupun terkadang kita kehilangan arah atau tidak sadar tentang kemampuan yang kita miliki (McLeod J, 2010:167). Sehingga meningkatkan self-control atau pengendalian diri menghadapi berubah dan beradaptasi yang baik antara diri sendiri dan dunia (Tangney et al, 2004).

Konseling kelompok SFBC dilakukankan dalam tujuh tahapan yaitu Identifying a solvable complaint (mengidentifikasi keluhan yang bisa dipecahkan); establishing goals (menetapkan tujuan); designing an intervention (merancang intervensi); strategic task that promote change(tugas strategis mempromosikan perubahan); Identifying dan emphazing new behavior and changes (perilaku baru yang positif dan perubahan 
diidentifikasi); stabilization (mengkonsolidasikan keuntungan); termination (pengakhiran).

Penelitian ini telah diusahakan dan dilaksanakan sesuai dengan prosedur ilmiah dan telah berhasil menguji cobakan konseling kelompok SFBCuntuk meningkatkan self-control pada siswa pelaku tawuran, namun demikian masih memiliki keterbatasan yaitu:

1. Dalam penelitian ini tidak dapat disimpulkan besarnya perbedaan dari ketiga teknik pada masing-masing kelompok karena tidak dapat dilakukan uji lanjut Post-Hoc Test sebab uji beda menggunakan Uji Kruskal-Wallis untuk non- parametrik.

2. Pada setiap kelompok tidak diberi kesempatan follow-updan tindak lanjut,sehingga keberhasilan intervensi pada setiap kelompok penelitian belum maksimal.

\section{KESIMPULAN}

Dalam simpulan akan dipaparkan mengenai hasil penelitian efektifitas konseling kelompok dengan teknik exception dan miracle question terhadap peningkatan selfcontrol pada siswa pelaku tawuran di SMK Nasional Cirebon, sebagai berikut:

a. Terdapat keefektifan konseling kelompok SFBC dengan teknik exception terhadap peningkatkan self-control pada kelompok A pada hasil uji hipotesis dengan analisis paired sample test, artinya bahwa konseling kelompok SFBC dengan teknik exception berhasil meningkatkan self-control pada siswa pelaku tawuran di SMK Nasional Cirebon.

b. Terdapat keefektifan konseling kelompok SFBC dengan teknik miracle question terhadap peningkatan self-control pada kelompok B, pada hasil uji hipotesis dengan analisis uji wilcoxon, artinya bahwa konseling kelompok SFBC dengan teknik miracle question berhasil meningkatkan self-control pada siswa pelaku tawuran di SMK Nasional Cirebon.

c. Terdapat keefektifan konseling kelompok SFBC dengan gabungan teknik exception danteknik miracle questionterhadap peningkatan self-control pada kelompok C pada hasil uji hipotesis dengan analisis paired sample test, artinya bahwa konseling kelompok SFBC dengan gabungan teknik exception dan teknik miracle question berhasil meningkatkan self-control pada siswa pelaku tawuran di SMK Nasional Cirebon. 
d. Terdapat perbedaan antara kelompok A, B dan kelompok $\mathrm{C}$ dari pre-test ke posttest, pada hasil uji perbedaan dengan analisis uji kruskal-wallis dan uji post hoc (uji lanjut), dimana nilai mean ranks tingkat self-control antara kelompok A, B dan kelompok $\mathrm{C}$ sesudah diberikan perlakuan menunjukkan paling rendah pada kelompok B dan paling tinggi pada kelompok C.

\section{DAFTAR PUSTAKA}

Ariningsun, A. 2014. "Penerapan Konseling Kelompok Rasional Emotif Perilaku Untuk Meningkatkan Pengendalian Diri Siswa Kelas VIII SMP Negeri 4 Panggul Trenggalek. Jurnal bk unesa,4(3). Doi: https://jurnalmahasiswa.unesa.ac.id/ index.php/jurnal-bk-unesa/article/view/8596.

Corey, G. 2009. Theory and Practice of Counseling and Psychotherapy. Belmont, CA: Brooks/Cole.

Corey, Gerald. 2013. Teori dan Praktek Konseling dan Psikoterapi. Bandung: PT. Refika Aditama.

DeWall, N., Denson, T.F., Finkel E.J., C. 2011. Self Control Inhibits Aggression. Social and Personality Psychology Compass. Blackwell Publishing Ltd.

Erford B. 2016. 40 Teknik Yang Harus Dikuasai Konselor. Edisi Ke Dua. Yogyakarta: Pustaka Pelajar.

Ghufron, M. Nur, \& Rini, Risnawati S.2014. Teori-Teori Psikologi. Yogyakarta. ArRuzz Media.

Mulawarman. 2014. "Brief Counseling in Schools: A Solution Focused Brief Counseling Approach For School Counselor In Indonesia”. Journal Of Education And Practice, 5(21). https://www.researchgate. net/publication/ $\underline{312991742 .}$.

Purwanto. 2016. Evaluasi Hasil Belajar. Yogyakarta: Pustaka Pelajar.

Sentana M.A \& Kumala I.D. 2017. "Agresivitas dan Kontrol Diri Pada Remaja Di Banda Aceh”. Jurnal Sains Psikologi, 6 (2): 51-55. Doi: http://journal2.um.ac.id/index.php/JSPsi/article/view/1602.

Tangney, J.P., Baumeister, R.F., \& Boone, A.L. 2004. "High Self-Control Predicts Good Adjustment, Less Pathology, Better Grades, and Interpersonal Success". Journal of Personality, 72(2) : 271-322. Doi: oi.org/10.1111/j.00223506.2004.00263.x

Tangney, J. P., Boone, A. L., \& Baumeister, R. F. 2018. High self-control predicts good adjustment, less pathology, better grades, and interpersonal success. In Self- 
regulation and self-control. Routledge: 181-220. Doi: $10.4324 \% 2 \mathrm{~F}$ 9781315175775-12

Titisari, H. T. D. 2018. "Hubungan antara Penyesuaian diri dan Kontrol diri dengan Perilaku Delikuen pada siswa SMA Muhammadiyah 1 Jombang”. PSIKODIMENSIA, 16 (2): 131-141. Doi: 103.243 .177 .137

Zahri, H., \& Savira, I. 2016. "Pengaruh Self-Control Terhadap Agresivitas Remaja Pada Pelajar Smp Dan Smu Di Sekolah Perguruan Nasional”. Jurnal Psikologi Pendidikan dan Pengembangan SDM, 4(1). Doi: http://ejournal.borobudur.ac.id/ index.php/ psikologi/ article/ viewFile/366/363. 